\title{
The Need to Reform the "Acceptance of Responsibility" Adjustment
}

Michael M. O'Hear

Marquette UniversityLaw School, michael.ohear@marquette.edu

Follow this and additional works at: http://scholarship.law.marquette.edu/facpub

Cart of the Law Commons

Publication Information

Michael M. O’Hear, The Need to Reform the "Acceptance of Responsibility" Adjustment, 9 Fed.

Sent'g Rep. 101 (1996). (C) 1996 by the Regents of the University of California on behalf of the Vera Institute of Justice. Copying and permissions notice: Authorization to copy this content beyond fair use (as specified in Sections 107 and 108 of the U. S. Copyright Law) for internal or personal use, or the internal or personal use of specific clients, is granted by the Regents of the University of California on behalf of the Vera Institute of Justice for libraries and other users, provided that they are registered with and pay the specified fee via Rightslink ${ }^{\circledast}$ on Caliber (http://caliber.ucpress.net/) or directly with the Copyright Clearance Center, http://www.copyright.com.

\section{Repository Citation}

O'Hear, Michael M., "The Need to Reform the "Acceptance of Responsibility" Adjustment" (1996). Faculty Publications. Paper 493. http://scholarship.law.marquette.edu/facpub/493

This Article is brought to you for free and open access by the Faculty Scholarship at Marquette Law Scholarly Commons. It has been accepted for inclusion in Faculty Publications by an authorized administrator of Marquette Law Scholarly Commons. For more information, please contact 


\section{THE NEED TO REFORM THE "ACCEPTANCE OF RESPONSIBILITY" ADJUSTMENT}

\section{Michael M. O'Hear ${ }^{\star}$}

Section 3E1.1 provides a two- or three-level reduction to the defendant who "clearly demonstrates acceptance of responsibility for his offense." Despite several amendments to the guideline and its commentary, the meaning of "acceptance of responsibility" remains vague. As a result, § $3 \mathrm{E} 1.1$ has become one of the most frequently litigated guidelines, and the Judicial Conference of the United States has called for a "fundamental reformation" of the provision. ${ }^{1}$ Much of the confusion may stem from a lack of clear purpose in the guideline. ${ }^{2}$ This article identifies two distinct animating principles in $\S 3 \mathrm{E} 1.1$-remorse and cooperation-discusses the manner in which courts have juggled these principles, and proposes a restructuring that would refocus the guideline on just one of them. My conclusion raises some larger questions about how the guidelines handle post-offense conduct.

\section{Background}

Section 3E1.1 grew out of the Commission's dilemma in deciding how guilty pleas should be treated under the guidelines. During the early phases of developing the guidelines, the Commission considered a proposal to provide a fixed, automatic "discount" for guilty pleas. ${ }^{3}$ Such a provision would have codified pre-guideline practices. The Commission's data indicated that defendants who pled guilty received, on average, sentences between thirty and forty percent lower than if they had gone to trial. ${ }^{4}$ Many viewed this plea discount as a necessary incentive to encourage guilty pleas, and guilty pleas as a necessary lubricant for an overburdened criminal justice system. ${ }^{5}$ Indeed, Commission research suggested that eightyfive percent of federal criminal sentences involved some form of plea bargaining. ${ }^{6}$ The automatic pleadiscount proposal would have retained an incentive for such plea bargaining, but in a more predictable form than during the pre-guideline era.

Nonetheless, the original Commission rejected the automatic discount, fearing that it might be construed as a penalty for defendants who exercised their constitutional right to a jury trial. ${ }^{7}$ Moreover, because it awarded a benefit for pleading guilty, regardless of the nature of the offense or other post-

* Law Clerk to Judge Janet Bond Arterton (D. Conn.). The views of the author do not necessarily reflect those of Judge Arterton. A longer version of this article will appear in the Northwestern Law Review in the summer of 1997. offense conduct, it was thought that the proposal might result in "unjustified windfalls" to some defendants, and "would not be in keeping with the public's perception of justice." 8

The Commission thus faced a conundrum: how could an encouragement for guilty pleas be built into the guidelines without incurring the disadvantages-and perhaps constitutional infirmities-of an automatic sentence discount? The Commission settled on the unique solution of $\S 3 \mathrm{E} 1.1$ : rather than rewarding guilty pleas per se, it invited judges to provide a benefit for "acceptance of responsibility" $(" \mathrm{a} / \mathrm{r}$ "). The oddity of this provision is revealed by its absence in state guideline systems. ${ }^{9}$ The Commission apparently felt that $\S 3 \mathrm{E} 1.1$ could advance the same purposes of an automatic plea discount without the unseemly results. What precisely were the advantages of the plea discount?

\section{A. The Cooperation Paradigm}

First, a guilty plea provided immediate, concrete benefits to society at large: "such pleas conserve the resources of the criminal justice system, and ... witnesses (particularly victims) are spared the stress of a trial."10 The "acceptance of responsibility" provision was designed to advance these interests by encouraging guilty pleas, but could also encourage other "socially desirable actions," such as "tak[ing] affirmative steps towards disassociation from past criminal conduct, and ... rectify[ing] the harm done to others."11 The intent of this prong of $\mathrm{a} / \mathrm{r}$ is to provide incentives for a defendant to engage in certain socially-desirable conduct-meaning primarily, though not exclusively, pleading guiltybetween the time of his offense and the time of sentencing. This is an expression of what I term the "cooperation paradigm" of $\S 3 \mathrm{E} 1.1$.

\section{B. The Remorse Paradigm}

In the Commission's view, however, rewarding guilty pleas (and a/r) also had another purpose, less oriented to gaining immediate benefits for society, and more oriented towards giving a break to defendants with certain personal characteristics. The Commission observed that "the guilty plea is the first step toward rehabilitation,'"12 and that other conduct demonstrating a/r (such as disassociation from criminal conduct and rectification of past harms) "is a sound indicator of rehabilitative potential."13 This hypothesis is associated with the second major animating principle of § 3E1.1, which I term the "remorse paradigm." Under this paradigm, § $3 \mathrm{E} 1.1$ is less concerned with the objective postoffense conduct of a defendant, and more concerned with the defendant's subjective state of mind towards his offense. Although conduct is a relevant indicator in this inquiry, conduct alone, no matter how cooperative, is not dispositive. 


\section{Balancing the Paradigms}

The Commission thus posited two purposes for rewarding a/r: (1) encouraging desirable postoffense conduct, and (2) recognizing rehabilitative potential. The Commission did not clearly indicate how judges were to weigh these purposes against one another. For instance, what of the defendant whose post-offense conduct provided substantial social benefits, but whose words and demeanor suggested little hope for rehabilitation? What of the defendant who went to trial and otherwise significantly taxed the criminal justice system, but who appeared genuinely to have turned over a new leaf in his life?

The application notes to $\S 3 \mathrm{E} 1.1$ reflect the Commission's attempts to balance the cooperation and remorse paradigms. For instance, judges are strongly discouraged from awarding the $\S 3 \mathrm{E} 1.1$ discount to defendants who go to trial or who receive an enhancement under $\S 3 \mathrm{C} 1.1$ for obstruction of justice. ${ }^{14}$ This seems much in the spirit of the cooperation paradigm: obstructing justice and putting the government to its burden of proof at trial may cause a waste of public resources and thwart other law enforcement agencies and such behavior is clearly to be discouraged. Yet, neither action necessarily indicates a lack of remorse or precludes the possibility of rehabilitation prior to sentencing. However, the defendant who goes to trial or obstructs justice is generally excluded from the § 3E1.1 benefit, even if he subsequently "admits guilt and expresses remorse."15

Although the guideline's treatment of defendants who go to trial or obstruct justice clearly emphasizes the cooperation paradigm, § 3E1.1 seems more oriented on its face towards remorse with respect to other defendants. In these cases, the $\mathrm{a} / \mathrm{r}$ inquiry is intended to be open-minded and discretionary. Application note one to $\S 3 \mathrm{E} 1.1$ lists several considerations that are "appropriate" to consider in this inquiry, but insists that this list is not meant to be exhaustive. Application note five states, "The sentencing judge is in a unique position to evaluate a defendant's acceptance of responsibility. For this reason, the determination of the sentencing judge is entitled to great deference on review." Why is the sentencing judge in such a "unique position"? The most obvious explanation lies in the sentencing judge's ability to determine whether the defendant has a remorseful demeanor. As an earlier draft of the application note expanded on this point: "The sentencing judge is in a unique position to evaluate whether the offender's post-offense conduct is sincere or merely self-serving." ${ }^{16}$ From this commentary, it is clear that the aspects of the application notes emphasizing the discretionary nature of the $\S$ 3E1.1 inquiry are associated with the remorse paradigm.

\section{Judicial Application of Acceptance of Responsibility}

Appellate courts generally take application note five's requirement of deference quite seriously, and tend concurrently to focus on the remorse paradigm. ${ }^{17}$ Denials of the a/r adjustment are usually upheld when the sentencing court has made any sort of express finding that the offender lacks contrition, even where the finding is wholly conclusory. ${ }^{18}$ Thus, appellate courts have provided little more guidance than has the Commission in how to implement the competing principles of $\S$ 3E1.1.19

Despite (or perhaps due to) the lack of guidance from the Commission and the appellate courts, trial courts seem to have largely treated $\S 3 \mathrm{E} 1.1$ as the automatic plea discount that the Commission originally considered and rejected. Overall, 84 percent of defendants receive the adjustment; ${ }^{20}$ data compiled by the Commission suggests that 88 percent of those who plead guilty receive a reduction, in comparison to only 20 percent of those who go to trial. ${ }^{21}$ As an Eighth Circuit panel remarked upon such data, "It may be that in each case additional factors [beyond the guilty plea] led the court to grant the reduction, but that seems unlikely."22

Furthermore, because of the lack of guidance from the Commission and the appellate courts, there is very little constraint on individual judges who implement a differing view of $\S 3 E 1.1$. And, indeed, there is some evidence of disparity. A 1989 analysis of four districts in the Eighth Circuit indicated that the percentage of defendants pleading guilty who receive the $\S 3 \mathrm{E} 1.1$ adjustment varied from fifty-four percent to eighty-six percent. ${ }^{23}$ A 1992 analysis of plea bargaining practices in three cities also presented evidence of disparity. ${ }^{24}$ In one district, judges awarded the reduction in over ninety percent of guilty-plea cases and an astonishing forty percent of cases going to trial-twice the national average. ${ }^{25}$ In another district, judges were similarly generous with guilty-plea cases, but awarded the discount to only twenty-five to thirty percent of defendants going to trial. ${ }^{26}$

One may also observe disparity in the published case law. For instance, in United States $v$. Harris, ${ }^{27}$ a robbery defendant who pled guilty was denied an $\mathrm{a} / \mathrm{r}$ adjustment for engaging in three types of noncooperative behavior: changing address without notifying the court, failing a drug test, and failing "to take advantage of opportunities for drug rehabilitation and counseling." ${ }^{28}$ In United States $v$. Schult $z,{ }^{29}$ by contrast, the defendant, who pled guilty to a money laundering offense, received a reduction notwithstanding an extensive list of similar behaviors: failure to complete a prescribed treatment program for alcohol abuse, refusal to provide urine samples, missed appointments with his probation 
officer, and an arrest for drunk driving, after which the defendant's pretrial release was revoked. ${ }^{30}$ It seems clear that the Schultz court employed a different standard for § $3 \mathrm{E} 1.1$ than that applied in Harris.

\section{Unresolved Problems with § 3E1.1}

The present state of $\S 3 \mathrm{E} 1.1$ raises numerous concerns. The ambiguity of the guideline produces an unnecessary quantity of appellate litigation and unwarranted sentencing disparity. Ambiguity also serves to undermine the underlying policy goals of the provision as stated by the Commission, i.e., recognizing rehabilitative potential and encouraging desired post-offense conduct. If judges focus primarily on rewarding desired conduct, then § 3E1.1 may not effectively serve to distinguish defendants who "enter the correctional system in a frame of mind that affords hope for success in rehabilitation" ${ }^{11}$ from those who do not. If judges focus primarily on state of mind, then the ability of $\S 3 \mathrm{E} 1.1$ to encourage desired behavior will be diminished. ${ }^{32}$

To the extent that $\S 3 \mathrm{E} 1.1$ actually functions as a plea discount, which seems to be the case in most districts, the guideline may also be criticized for a certain dishonesty. There is a disjunction between the rhetoric of the Commission and the appellate courts, which emphasizes remorse, and the reality of day-to-day implementation of the guideline. This disjunction is troubling in light of the supposed "truth in sentencing" goal of the guidelines. The need for openness in the context of § 3E1.1 may be particularly acute, for the provision trenches on the rights of defendants to trial by jury. When a reduction that is routinely granted to over eighty percent of defendants is generally denied to defendants who go to trial, one may easily reconceptualize the "reduction" provision as a penalty imposed for exercising a constitutional right. Such a penalty may or may not be good public policy, and it may or may not be permitted by the Constitution, but the precise contours of the penalty should be fully open to judicial review and public debate.

Finally, the remorse element of $\S 3 E 1.1$, while more prevalent in appellate case law than in the practices of district courts, raises a variety of concerns in and of itself. Plainly, the remorse inquiry will be affected by an offender's performance in the court and during meetings with probation officers. Yet, quality of performancewords of contrition, humble demeanor, etc.-may be less a function of "rehabilitative potential" than of coaching by a good lawyer, intelligence, mental health, and experience in interacting with people who belong to the racial and socioeconomic classes from which most judges and probation officers come. ${ }^{33}$ A remorse adjustment risks bias against certain groups, and may largely reward those capable of manipulating the expectations of judges and probation officers. As the Ninth Circuit recently noted, in a rare appellate decision that explores the purposes of $\S 3 \mathrm{E} 1.1$ at some length, "There is no particular purpose to be served by lenience towards those who cry more easily, or have sufficient criminal experience to display sentiment at sentencing instead of restraining their emotions in public." 34 As Judge Frankel has written, "The effort to appraise 'character' is, to be sure, a parlous one, and not necessarily an enterprise for which judges are notably equipped by prior training." 35

In light of such concerns, $\S 3 \mathrm{E} 1.1$ is clearly in need of reform. Indeed, the Commission itself has not been insensitive to the problems surrounding the guideline. In 1991, a working group prepared a lengthy report on acceptance of responsibility. ${ }^{36}$ Unfortunately, although the working group raised important questions concerning ambiguity, disparity, and appropriate distinctions between different types of post-offense conduct, the group's report focused on relatively narrow proposals to add an extra level of discount to $\S 3 \mathrm{E} 1.1$ and to address selfincrimination concerns that had produced a circuit split. The working group's discussion of these matters was thoughtful and surely contributed to subsequent amendments of the guideline, but the bigger questions received short shrift. ${ }^{37}$

\section{Proposals for Reform}

As the Judicial Conference has suggested, the time is ripe for more substantial reform of $\S 3 \mathrm{E} 1.1$. In particular, I propose that the provision be clearly focused on one purpose, specifically, encouraging desired post-offense conduct. Section 3E1.1 might be restructured along the following lines:

\section{§3E1.1 Adjustment for Cooperative Behavior}

(a) The sentencing judge may reduce the offense level by 0 to 3 levels based on the degree to which the defendant's post-offense conduct facilitates the efficient and fair administration of the criminal justice system and the recovery and restoration of victims.

(b) For defendants who plead guilty and do not otherwise engage in any significantly cooperative or uncooperative conduct, the presumptive reduction shall be 2 levels.

(c) For defendants who go to trial and do not otherwise engage in any significantly cooperative or uncooperative conduct, the presumptive reduction shall be 0 levels.

This proposal is consistent with the spirit of the recent Judicial Conference proposal, which seeks to reform § 3E1.1 such that the guideline will no longer "tr[y] to do too much with one adjustment." ${ }^{\prime 38}$ 
However, the reconceptualization of $\S 3 \mathrm{E} 1.1$ proposed here as a cooperation adjustment may lend even greater clarity and coherence to the guideline than the Judicial Conference's proposal. ${ }^{39}$

The cooperation adjustment is generally consistent with existing practices. Those who plead guilty will routinely receive a benefit and those who go to trial will not. But, also as in the present system, these adjustments would not be automatic: defendants who plead guilty may still lose their benefit for violating the terms of pretrial release, obstructing justice, or engaging in comparably poor behavior. Defendants who go to trial may still qualify for a reduction based on other aspects of post-offense conduct. Judges would have greater flexibility in awarding § 3E1.1 benefits: rather than an all-or-nothing two-point reduction with a potential third-point available to a small class of defendants, judges would be permitted to reduce any sentence by one, two, or three points. ${ }^{40}$ On the other hand, judges would be precluded from denying the benefit based on unremorseful demeanor or on statements by the defendant not rising to the level of obstruction of justice. In short, the remorse paradigm would be stripped out of $\S 3 \mathrm{E} 1.1 .^{41}$

Alternatively, the Commission might consider either returning to the notion of a fixed, automatic plea discount, or eliminating § 3E1.1 altogether. Both solutions would address the current ambiguity of the guideline, as well as the problematic role of remorse in the current system, but both of these solutions present difficulties of their own. A plea discount offers less flexibility than a cooperation discount, leaving much cooperative behavior unrewarded, and possibly producing the sorts of unseemly results that originally concerned the Commission. Eliminating § 3E1.1 altogether would likewise reduce incentives for cooperative postoffense conduct. Indeed, removing § $3 \mathrm{E} 1.1$ would take away the one explicit plea inducement provision in the guidelines. Much research suggests that plea bargaining would still continue without such a provision, ${ }^{42}$ but elimination of $\S 3 \mathrm{E} 1.1 \mathrm{might}$ "drive plea inducements further underground, with the result of even more arbitrariness and disparity." 43

\section{The Broader Issues}

The problems of acceptance and plea inducement point to larger dilemmas of guideline sentencing, particularly the proper treatment of post-offense conduct. Such conduct is presently handled in a fragmentary way, touched on by such disparate provisions as $\S 3 \mathrm{E} 1.1, \S 5 \mathrm{~K} 1.1$ (departure for substantial assistance to authorities), $\S 3 \mathrm{C} 1.1$ (obstructing or impeding the administration of justice), $\S 3$ C1.2 (reckless endangerment during flight), and § 1B1.3 (relevant conduct). A reform of $\S 3 \mathrm{E} 1.1$, such as I have proposed, that places the guideline more clearly among this body of provisions invites reconsideration of how these provisions relate to one another and fit into the guideline scheme as a whole.

The linkages between $\S 5 \mathrm{~K} 1.1$ and $\S 3 \mathrm{E} 1.1$, particularly when the latter is conceptualized as a cooperation adjustment, are especially noteworthy. The substantial assistance provision seems a rather anomalous guideline at present: defendants who provide "substantial" assistance in the investigation or prosecution of another person, and who receive a motion for departure from the government, may benefit from a potentially limitless downward departure-they may be sentenced anywhere below the suggested guideline range. But defendants who, try as they might, do not succeed in providing the right kind or degree of assistance-maybe simply because they are small-time criminals who are not capable of aiding the prosecution of others-or who cannot obtain favorable treatment from a fickle prosecutor, are not provided any express benefit under the guidelines. ${ }^{44}$ Yet, a defendant may provide meaningful assistance to the government that does not rise to the level of substantial, as, for instance, by pleading guilty.

My proposal would render $\S 5 \mathrm{~K} 1.1$ less anomalous by clearly providing incentives for intermediate assistance. Yet, such reform would also underscore other problematic aspects of $\S 5 \mathrm{~K} 1.1$. Why, for instance, should the $\S 5 \mathrm{~K} 1.1$ benefit only be available upon a prosecutor's motion, while $\S 3 E 1.1$ rests on a judge's discretion? Why should $\S 5 \mathrm{~K} 1.1$ entirely "drop the floor" from beneath a defendant, while $\S 3 E 1.1$ provides a benefit subject to clear limitations? Perhaps the two provisions should be combined, or at least restructured, so as to function in a more complementary fashion.

The chapter $3 \mathrm{C}$ guidelines, which provide enhancements for obstruction of justice and reckless endangerment during flight, might also be better integrated with a reformed $\S 3 \mathrm{E} 1.1$. Both obstruction and reckless endangerment seem quite appropriate considerations in a cooperation inquiry. In the interests of simplicity and clarity, the 3C guidelines might thus be eliminated altogether. ${ }^{45}$ Merger of 3C and 3E would also diminish the current problem that defendants who plead guilty are subject to much greater penalties for obstruction than defendants who go to trial. The defendant who pleads will normally receive a two or three level reduction, but if such a defendant obstructs justice, he will receive the two-level $\S 3 \mathrm{C} 1.1$ enhancement and also lose his § $3 E 1.1$ benefit. Merger would permit similar acts of obstruction to be treated similarly, regardless of mode of conviction.

Enlarging the scope of a reformed § $3 \mathrm{E} 1.1$ and merging the provision with other guidelines might thus enhance their integrity. However, larger questions remain: How should non-offense conduct 
be weighed in the context of a sentencing scheme designed to "avoid unwarranted sentencing disparities among defendants with similar records who have been found guilty of similar conduct?" 46 How can the principle of proportionality in sentencing be reconciled with the purely utilitarian imperatives that lie behind something like a cooperation adjustment? How can the magnitude of adjustments for post-offense conduct be appropriately scaled, such that the number of levels added or subtracted bears some rational relationship to the implicit ranking of social harms set forth in Chapter Two?

\section{Conclusion}

However it addresses such questions, the Commission would do well to bear in mind one of the most salient lessons of the § $3 \mathrm{E} 1.1$ experience: The institutional pressures and constraints facing district courts, as well as the individual perspectives of sentencing judges, impose significant limitations on top-down sentencing reforms. Although the Commission expressly disavowed an automatic plea benefit, § 3E1.1 has generally become just that. Indeed, §3E1.1 is not the only example of this phenomenon; other observers have noted the pressures for masked avoidance of the guidelines. ${ }^{47}$ Thus, it is far from clear that unwarranted disparity is any less frequent now than in the pre-guideline era. ${ }^{48}$ Guided discretion in sentencing remains a compelling vision; however, guidance will not succeed unless sentencing actors are willing and able to be guided. Guidance must be clear, principled, and ultimately founded on the accumulated wisdom of the nation's sentencing courts.

\section{NOTES}

${ }^{1}$ See Letter from Maryanne Trump Barry, Chair of the Committee on Criminal Law of the Judicial Conference, to Judge Richard P. Conaboy, Chairman of the Sentencing Commission (Dec. 5, 1995) (see appendix to this article) [hereinafter Judicial Conference Amendment]. Section 3E1.1 accounts for the third highest number of appeals among guidelines provisions by both defendants (after the drug guidelines and relevant conduct) and the government (after drug guidelines and departures).

${ }^{2}$ As to purpose, the commentary to § $3 E 1.1$ unhelpfully states, "For several reasons, a defendant who clearly demonstrates acceptance of responsibility ... is appropriately given a lower offense level than a defendant who has not demonstrated acceptance of responsibility." § 3E1.1, comment. (backg'd).

${ }^{3}$ See William W. Wilkins, Jr., Plea Negotiations, Acceptance of Responsibility, Role of the Offender, and Departures: Policy Decisions in the Promulgation of Federal Sentencing Guidelines, 23 WAKE FOREST L. REV. 181, 190 (1988).
${ }^{4}$ See id. at 191.

${ }^{5}$ See Stephen Breyer, The Federal Sentencing Guidelines and the Key Compromises Upon Which They Rest, 17 Hofstra L. Rev. 1, 29 (1988).

${ }^{6}$ See id. at 29-30.

${ }^{7}$ See id. at 28.

${ }^{8}$ Wilkins, supra note 3 , at 191.

${ }^{9}$ See U.S. Sentencing Commission, Staff Discussion Paper: Chapter Three Adjustments, at appendix 7 (1995) [hereinafter Staff Discussion Paper] (noting that Minnesota, Oregon, Michigan, Virginia, and Pennsylvania do not have $\mathrm{a} / \mathrm{r}$ guidelines).

${ }^{10}$ U.S. Sentencing Commission, Preliminary Draft of Sentencing Guidelines § B321, comment. (Sept. 1986) [hereinafter 1986 Draft].

${ }^{11} \mathrm{Id}$.

${ }^{12}$ Id. See also Brady v. United States, 397 U.S. 742, 753 (1969) (a defendant "demonstrates by his plea that he is ready and willing to admit his crime and to enter the correctional system in a frame of mind that affords hope for success in rehabilitation over a shorter period of time than might otherwise be necessary.").

${ }^{13} 1986$ Draft, supra note 10 , at $\S$ B321, comment.

${ }^{14} \S 3 \mathrm{E} 1.1$, comment. (nn. 2,4).

${ }^{15} \mathrm{Id}$. (n.2).

${ }^{16} 1986$ Draft, supra note 10 , at § B321, comment.

${ }^{17}$ See, e.g., United States $v$. Spires, 79 F.3d 464, 467 (5th Cir. 1996) (referring to the $\S 3 E 1.1$ inquiry as "the trial court's assessment of a defendant's contrition"); United States v. Eyler, 67 F.3d 1386, 1390-91 (9th Cir. 1995) ("[T]he key inquiry for purposes of section (a) is whether the defendant has demonstrated contrition ...."); United States v. Echevarria, 33 F.3d 175, 179 (2d Cir. 1994) (holding that defendant may be denied $\mathrm{a} / \mathrm{r}$ adjustment for failing "to acknowledge the wrongfulness of his acts"); United States $v$. Cousineau, 929 F.2d 64, 65-66 (2d Cir. 1991) ("[O]ne who is without remorse and fails to acknowledge that his behavior was wrong clearly is not entitled to a reduction for acceptance of responsibility ...."); United States $v$. Royer, 895 F.2d 28, 30 (1st Cir. 1990) ("In deciding whether a defendant is entitled to a reduction .... . a district court must weigh a multitude of factors .... [to] determin[e] whether [the] person is genuinely contrite."); United States v. Cook, 922 F.2d 1026, 1037 (2d Cir. 1990) (noting that "acceptance of responsibility necessitates candor and remorse"). See also Thomas Hutchison \& David Yellen, Federal Sentencing Law \& Practice 513 (2d ed. 1994) ("What the Commission seems to have intended in that the defendant be sincerely contrite. The few reported decisions are consistent with this analysis.").

18 See, e.g., United States v. Zanni, 64 F.3d 654, 654 (1st Cir. 1995) (upholding denial of $\mathrm{a} / \mathrm{r}$ adjustment when district court "was not persuaded that [defendant] was genuinely contrite"); United States $v$. Boothe, 994 F.2d 63, 71 (2d Cir. 1993) (upholding denial of adjustment when district court had relied on the fact that defendant "failed to prove the sincerity of his acknowledgment of guilt"); United States v. Austin, 948 F.2d 783, 787-88 (1st Cir. 1991) 
(upholding denial of adjustment when district court "remained unconvinced the [defendant] had any remorse whatever"); United States $v$. Whitehead, 912 F.2d 448, 451 (10th Cir. 1990) (upholding denial of adjustment based in part on finding that defendant "did not accept fully that his actions were morally and legally improper"); United States v. Hill, 911 F.2d 129, 131 (8th Cir. 1990) (upholding denial of adjustment based on fact that defendant "did not express sorrow or state that he wished he had not committed the crime").

${ }^{19}$ See Dan Freed \& Marc Miller, Editors' Observations: Plea Bargained Sentences, Disparity and "Guideline Justice," 3 FED. SENT. R. 175, 176 (1991) (“When . . judges deny the discount, appellate courts rarely reverse or set standards for even-handed administration." (citation omitted)).

${ }^{20}$ See Staff Discussion Paper, supra note 9, at appendix 2.

${ }^{21}$ See U.S. Sentencing Commission, Acceptance of Responsibility Working Group Report 5 (1991) [hereinafter Working Group Report].

${ }^{22}$ United States v. Knight, 905 F.2d 189, 192 (8th Cir. 1990)

${ }^{23}$ See Gerald W. Heaney, Revisiting Disparity: Debating Guidelines Sentencing, 29 AM. CRIM. L. REv. 771, 775 (1992). The percentage of defendants going to trial who received the benefit varied from two percent to thirty-three percent. These numbers, of course, need not necessarily represent unwarranted disparity. It may be the case that, due to the nature of crime prosecuted or other factors differentiating the districts, there are important $\mathrm{a} / \mathrm{r}$-related differences among the populations of defendants being sentenced-for instance, the defendants in one district may actually be more remorseful than those in the others. Unfortunately, strictly numerical comparisons, such as those offered by Judge Heaney, are not able to incorporate such factors into the analysis.

${ }^{24}$ See Ilene H. Nagel \& Stephen J. Schulhofer, A Tale of Three Cities: An Empirical Study of Charging and Bargaining Practices Under the Federal Sentencing Guidelines, 66 S. CAL. L. Rev. 501 (1992).

${ }^{25}$ See id. at 531,550

${ }^{26}$ See id. at 540. The Nagel \& Schulhofer study does not provide exact numbers because the authors wished to preserve the anonymity of the districts they studied.

${ }^{27} 13$ F.3d 555 (2d Cir. 1994).

${ }^{28} \mathrm{Id}$. at 557 . The appellate court upheld the denial of a reduction on these grounds.

${ }^{29} 880$ F. Supp. 605 (N.D. Ind. 1995).

${ }^{30} \mathrm{Id}$. at 608-09. The court remarked simply, "Mr. Schultz performed poorly with respect to the conditions of his pretrial supervision."

${ }^{31}$ Brady v. United States, 397 U.S. 742, 753 (1969).

${ }^{32}$ As Professor Schulhofer has observed, "The line of thought reflected in [cases in which the remorse aspect of $a / r$ is emphasized], if pursued seriously, could quickly destroy the value of the acceptance-of-responsibility discount as a plea-inducing device." Stephen J. Schulhofer, Implementing the Plea Agreement Provisions of the Federal Sentencing Guidelines, 3 FED. SENT. R. 179, 180 (1991).

${ }^{33}$ For examples of two troubling cases in which a defendant was denied the $\S 3 \mathrm{E} 1.1$ reduction for oral statements made to the court, not withstanding evidence of mental illness, see United States v. Echevarria, 33 F.3d 175 (2d Cir. 1994); United States v. Altman, 901 F.2d 1161 (2d Cir. 1990). Altman was reversed on appeal; Echevarria was not.

${ }^{34}$ United States v. Vance, 62 F.3d 1152,1159 (9th Cir. 1995).

${ }^{35}$ United States v. Hendrix, 505 F.2d 1233, 1236 (2d Cir. 1974).

${ }^{36}$ See Working Group Report, supra note 21.

${ }^{37}$ For instance, it is difficult to discern the source of the working group's confident conclusion, "Although variations with respect to the application of the acceptance of responsibility adjustment do exist, the Commission may conclude that they are not too pronounced." Id. at 7. Elsewhere, the working group noted, "Several statements [of individuals interviewed in connection with a broader study of the Guidelines] suggest that acceptance of responsibility is applied differently across the nation and within a given district." Id. at 24. Moreover, the working group's cursory review of a random sample of case files revealed a number of troubling results, including three cases in which defendants received the $\mathrm{a} / \mathrm{r}$ adjustment despite going to trial and despite maintaining their innocence after conviction. Finally, the working group's data on variation was maddeningly incomplete. For instance, the report states that in only five districts do judges grant the reduction to fewer than seventy-five percent of defendants who plead guilty. $I d$. at 6 . However, the report does not indicate how much below seventy-five percent those districts are, whether there are any districts that are outliers in the opposite direction (e.g., granting the adjustment to more than ninety percent of defendants who plead), or whether significant variation exists within districts.

${ }^{38}$ Judicial Conference Amendment, supra note 1, at 1 . On January 2 , the Commission published a proposed amendment that would modify § $3 E 1.1$ in significant ways. 62 Fed. Reg. 179-80 (1997) (Amendment 24). This proposal would also narrow the scope of the $\mathrm{a} / \mathrm{r}$ inquiry, at least with respect to the two-level reduction provided in 3E1.1(a). Amendment 24 will be further examined in a subsequent Issue of FSR.

${ }^{39}$ The Judicial Conference's approach, delineated in three alternative proposals, divides the § 3E1.1 inquiry into distinct and independent inquiries. For instance, "Option 2" would award a one-point reduction to defendants who demonstrate "acceptance of responsibility," one point to defendants who plead guilty, and an additional point to defendants who plead guilty in a "timely" manner. Id. at 6 . Thus, the proposal would leave the ambiguous concept of "acceptance of responsibility" in the guidelines, but would reduce its significance to one point. In contrast, my proposal would remove "acceptance of responsibility" from the guideline altogether and expressly focus the $\S 3 \mathrm{E} 1.1$ inquiry on cooperation. These changes would leave the guideline both more objective and more capable of recognizing the range of post-offense 
conduct that society might wish to encourage. My proposal may be similarly differentiated from the Commission's proposed Amendment 24.

${ }^{40} \mathrm{Granting}$ judges discretion to reduce any sentence by as many as three points may raise problems with respect to the "25\% rule." 28 U.S.C. § 994(b)(2). Under the traditional "inclusive" interpretation, "the $25 \%$ rule applies to all steps in the guideline process, restricting all kinds of guideline formulations available, and requiring numerical adjustments for each sentencing factor." Catharine M.

Goodwin, Background of the AO Memorandum Opinion on the 25\% Rule, 8 FED. SENT. R. 109 (1995). If this interpretation is accepted, then the third point of $\mathrm{a} / \mathrm{r}$ adjustment may have to be limited to defendants with high offense levels, as is presently the case under $\S 3 \mathrm{E} 1.1$. However, critics of the inclusive interpretation have argued convincingly that the $25 \%$ rule should be limited to its plain meaning, i.e., that the rule is only applicable to the ranges in the Sentencing Table itself. Id.

${ }^{41}$ One of the purposes of the proposal is to reduce the role of remorse in sentencing, which I find to be problematic in light of the difficulties of truly knowing a defendant's mind based on generally brief courtroom encounters and in light of the risk that the assessment of remorse may be clouded by issues of race, class, temperament, criminal experience, and mental illness. However, my proposal would not wholly preclude judges from taking account of a defendant's attitude in sentencing: a judge could use remorse as a basis for sentencing at the bottom of the applicable range, or defiance for sentencing at the top. Remorse might also be a basis for departure-indeed, remorse-based departures would grow more easy under my proposal because it would be clear that the Commission did not already take remorse into account in § 3E1.1. However, under my proposal there would be less room overall for remorse-based considerations in sentencing. Attitude would be only one factor most judges would want to take into account in sentencing within a range, and the size of the range is itself rather limited in many cases. Departures would provide greater degrees of recognition for remorse, but would be subject to a much more searching form of appellate scrutiny than the current $\mathrm{a} / \mathrm{r}$ determinations.

${ }^{42}$ Several studies suggest that plea differentials persist even when jurisdictions "ban" plea bargaining. See, e.g., Richard S. Frase, Implementing Commission-Based Sentencing Guidelines: The Lessons of the First Ten Years in Minnesota, 2 Cornell J.L. \& Pub. PoL'Y 279, 316-17; Robert A. Weninger, The Abolition of Plea Bargaining: A Case Study of El Paso County, Texas, 35 UCLA L. Rev. 265, 311 (1987). For a discussion of the subtle tools of plea inducement available to prosecutors above and beyond § 3E1.1, see Nagel \& Schulhofer, supra note 24 , at 547-49.

${ }^{43}$ Schulhofer, supra note 32 , at 180 (discussing consequences on plea-bargaining of remorse-oriented decisions).

${ }^{44}$ The absence of any provision in the guidelines to benefit defendants who provide assistance to the authorities but fail to obtain a prosecutor's motion for departure seems curious in light of 28 U.S.C. § 994(n), which requires the Commis- sion to "assure that the guidelines reflect the general appropriateness of imposing a lower sentence than would otherwise be imposed ... to take into account a defendant's substantial assistance in the investigation or prosecution of another person who has committed an offense."

${ }^{45}$ If this reform were adopted, § $3 \mathrm{E} 1.1$ should be restructured so that it could provide a net enhancement, rather than just a net reduction; otherwise, defendants who went to trial would generally not be subject to penalties for obstruction or reckless endangerment because such defendants would presumptively not receive a § $3 \mathrm{E} 1.1$ adjustment anyway-leaving such defendants with literally nothing to lose by obstruction or endangerment.

${ }^{46} 18$ U.S.C. $§ 3553$.

${ }^{47}$ Daniel J. Freed, Federal Sentencing in the Wake of Guidelines: Unacceptable Limits on the Discretion of Sentencers, 101 YALE L.J. 1681, 1726-27 (1992).

${ }^{48} I d$. at 1684 n. 5 (citing survey of federal district judges).

\section{Appendix}

In a letter dated December 5, 1995, Judge Maryanne Trump Barry, Chairwoman of the Committee on Criminal Law of the Judicial Conference of the United States, wrote a letter to Judge Richard Conaboy, Chairman of the United States Sentencing Commission, urging that the Commission consider two amendments to the sentencing guidelines, notwithstanding the Commission's initiation of a broader program to review and assess the guidelines. One of these "specific and narrowly focused amendments" concerned revision of $\S 3 E 1.1$. Following are the relevant portions of the Judicial Conference's submission to Judge Conaboy.

\section{A PROPOSED AMENDMENT TO § 3E1.1 (ACCEPTANCE OF RESPONSIBILITY)}

Fundamental reformation of the acceptance of responsibility guideline, $\S 3 \mathrm{E} 1.1$, is needed, primarily because the various factors which comprise the current "acceptance" adjustment interact with each other not only to generate needless litigation, but to deny the utility of a separate, independent incentive solely for the entry of a plea. As a consequence, either the other factors interfere with the court's ability to reward a plea, or, if the reduction is rewarded for a plea, the other factors are lost. The court is unable to distinguish between a begrudging, reluctant timely plea (for which the full three points must be awarded), and a timely "plea plus" where the defendant pleads as well as shows genuine remorse, demonstrates assistance to authorities, has undergone post-offense rehabilitative efforts, and/or some of the other factors which the guideline attempts to reward. 


\section{A. Interfering Factors: Need for Separate Plea Incentive}

The case law indicates continued confusion with the way the acceptance of responsibility guideline has come to be interpreted. Astonishingly, the acceptance guideline accounts for the third highest number of appeals. ${ }^{1}$ This confusion is generated by the interaction and definition of the numerous factors listed in the current acceptance guideline, all of which comprise the vague concept of "acceptance." 2 Commission data shows that nearly a third of the appeals in FY 1994 involving this guideline were based on "application and definition issues." 3

Factors such as how much the defendant has to "admit" (or not "falsely deny"), the timeliness of the plea, the extent of the defendant's remorse, or the extent of the government's "preparation," account for much of the litigation and confusion surrounding this guideline, because the determination of the entire guideline can turn on these issues. Worse, they cloud and complicate the court's efforts, and need, to reward the entry of a plea in order to conserve judicial and other resources. The current guideline tries to do too much with one adjustment (the separate adjustment has not been effective, as discussed below), and consequently it does not serve any of its numerous goals well.

Any plea incentive is inextricably intertwined with issues of attitude, other conduct, the government's preparation, etc. which either get lost in the overwhelming thrust to reward a plea, or worse, prevent the plea incentive from working. How does a court reward the entry of a plea where the defendant has done something (perhaps submitted a bad urine sample) which arguably prevents the allowance of the first 2-level adjustment? There is no way to provide a reward for the many non-plea incentives listed in $\S 3 \mathrm{E} 1.1$ if the court rewards the entry of the plea; the other incentives either over-come the plea incentive, or vice versa. In a case where the defendant agrees to simply enter a timely plea, and if the court rewards the plea, it must do so with the full three points (as discussed below), with no adjustment left to act as an incentive for the other commendable conduct which the guideline attempts to encourage.

The Commission has always stopped short of allowing an adjustment solely for the entry of a plea. The plea incentive is merely one of many incentives. "Plea" is not even mentioned in the 2-level adjustment part of the guideline. However, the Commission has moved in the direction of directly rewarding a plea. A 1990 amendment sought to clarify that the adjustment is generally not available to a defendant who puts the government to its proof at trial, expressing remorse only on conviction. ${ }^{4}$ In addition, a 1992 amendment moved from guideline to commentary the statement that the court could consider imposing the reduction without regard to whether the conviction was based on a plea or a trial, and it added the third level adjustment, one basis for which is the entry of an early plea. ${ }^{5}$

\section{B. Constitutionality of Separate Plea Incentive}

The Commission need not be reluctant to provide a direct incentive for a plea, because it is clear from long-standing Supreme Court law, as well as a comprehensive reading of appellate cases on the current guideline, that a plea reward would be upheld as constitutional and justified by the benefit which a plea brings the system. The rationale would no doubt be the same as that used by the Supreme Court in upholding plea bargaining, a procedure which offers a discounted sentence for a plea in order to provide the benefit of the plea to the system.

While the Supreme Court has not ruled on the constitutionality of the current acceptance of responsibility guideline, ${ }^{6}$ it has established a solid body of case law upholding plea bargaining practices or statutes which result in lower sentences for those who plead than for those who go to trial. In Corbitt $v$. New Jersey, 439 U.S. 212, 99 S. Ct. 492 (1978), a New Jersey statute was challenged that mandated a life sentence for a defendant convicted by a jury of first degree murder, but allowed the possibility of a lesser sentence if the defendant entered a plea. The Supreme Court held that states may encourage guilty pleas by reducing the sentences imposed after a plea. The court stated that "not every burden on the exercise of a constitutional right and not every pressure or encouragement to waive such a right is invalid." Id. at 218.7 Similarly, in Bordenkircher $v$. Hayes, 434 U.S. 357, 363, 98 S. Ct. 663, 668 (1978), the Court upheld the government's right to withhold leniency for a homicide defendant who went to trial, and held that the key to the constitutionality of plea bargaining is whether the defendant has the freedom to choose between sentence options.

In these cases the court relied on its own previous cases sustaining plea bargaining, a practice which inherently rewards pleas and "penalizes" those who go to trial. For example, in U.S. v. Brady, 397 U.S. 742, 752, 90 S. Ct. 1463, 1471 (1970), the Court held that the preservation of prosecutorial and judicial resources justifies a sentencing scheme that favors guilty pleas and justifies plea bargaining. These same rationales would apply to a sentence reduction for the entry of a plea in the guideline context. $^{8}$

\section{The All or Nothing, "Tello" Problem}

An extra, third point adjustment for an early plea or cooperation was added in $1992 .{ }^{9}$ While the goal might have been to provide more flexibility in rewarding particularly early pleas, the result in practice has been to require all three levels for any plea which is conceivably "timely." Its potential usefulness was limited by the fact that the defendant must have qualified for the 2-level provision before 
he or she can be considered for the extra, third level adjustment.

The courts have reinforced this tie, as demonstrated by U.S. v. Tello, 9 F.3d 1119 (5th Cir. 1993), where the court held that once a court awards the 2level adjustment for a "timely" plea, the court has no discretion but to award the third point, as well. In that case the defendant gave false information to the probation officer about his criminal history and caused additional investigation to be conducted. The sentencing court increased the sentence for obstruction, but, in spite of the guidelines' admonition to the contrary, ${ }_{10}^{10}$ the sentencing court also gave the defendant the 2-level acceptance reduction because he entered a "timely" plea, but withheld the third level reduction because of the obstruction. The Fifth Circuit held that the court had no discretion to withhold the extra level if it imposed the 2-levels on the basis of a timely plea. The court said that the obstruction "evaporated" once the court awarded the 2-points, and then all that mattered was whether the criteria of the extra point reduction applied. ${ }^{11}$ Therefore, the court must award 3 levels, if any at all, for a timely plea, with no ability to adjust the total reduction for any of the other factors involved.

Nor could the court have done the reverse: deny the 2-level adjustment because of the obstruction (or some other non-plea reason), but impose the onelevel adjustment to attempt to reward the timely plea. This was, in fact, what the sentencing court tried to do in U.S. v. Solis, 39 F.3d 568 (5th Cir. 1994). There it did not award the 2-levels in § 3E1.1(a) for several reasons, mostly unrelated to timeliness of the plea, but then imposed the 1-level for the timely plea. The sentence was reversed on appeal. However, the appellate court noted the irony that the one point provision (which mentions a plea) cannot be imposed if the 2-point provision (which does not mention a plea) is denied, even for some non-plea reason.

These cases illustrate not only the problem with the extra point adjustment, but also the need for a separate plea incentive, in order to avoid confusion and interference between the reward for a plea and the reward (or withholding of the reward) for the other incentives provided in the guideline.

\section{Conclusion}

The current guideline has generated confusion and litigation. More importantly, it does not allow the court to distinguish between a defendant who merely pleads guilty and one who also does some of the things described in Application Note 1. Admittedly a court could decide that merely pleading guilty is not enough to be "acceptance of responsibility." However, all courts are confronted with the inescapable fact that, with the increasing federalization of crime, our criminal justice system could not function without a large number of guilty pleas, even if the defendant is willing to do little more than enter the plea. Our proposal recognizes that reality, but allows an additional decrease for the defendant who does more. Options 2 and 3 would make a clear distinction between a guilty plea and a "timely" guilty plea. We would also support a possible 4-level discount in larger cases, as in Option 3, if the Sentencing Commission determines this to be acceptable.

Application Note 1 would remain substantially as it is, as a listing of criteria applicable to the determination of the "acceptance of responsibility" provision in our proposals. We suggest that a factor be added to that listing: whether the defendant cooperated with the probation officer in providing information necessary for the preparation of the presentence report. The remainder of the commentary would be streamlined to a bare minimum.

\section{E. Proposed Guidelines: § 3E1.1}

The Committee asks that the Commission adopt one of the following amendments, as a replacement for the current acceptance of responsibility guideline:

\section{§ 3E1.1 Acceptance of Responsibility}

Option 1:

(a) Decrease the offense level by up to 3 levels according to the following, independently determined, factors:

(1) If the defendant timely enters a plea of guilty, thereby permitting the government to avoid preparing for trial and permitting the court to allocate its resources efficiently, decrease the offense level by 2 levels; and

(2) If the defendant otherwise clearly demonstrates acceptance of responsibility for the offense, decrease the offense level by 1 level.

(b) Notwithstanding the above, if the defendant's offense level determined prior to the operation of this guideline is below 16, decrease the offense level by no more than 2 levels for this guideline.

\section{Option 2:}

(a) Decrease the offense level by up to 3 levels according to the following, independently determined, factors:

(1) If the defendant enters a plea of guilty, decrease the offense level by 1 level;

(2) If the plea of guilty is timely entered, thereby permitting the government to avoid preparing for trial and permitting the court to allocate its resources efficiently, decrease the offense level by 1 level; and

(3) If the defendant otherwise clearly demonstrates acceptance of responsibility for the offense, decrease the offense level by 1 level.

(b) Notwithstanding the above, if the defendant's offense level determined prior to the operation of this guideline is below 16, decrease the offense level by no more than 2 levels for this guideline. 


\section{MICHAEL M. O'HEAR}

\section{Option 3:}

(a) Decrease the offense level by up to 4 levels according to the following, independently determined, factors:

(1) If the defendant enters a plea of guilty, decrease the offense level by 2 levels;

(2) If the plea of guilty is timely entered, thereby permitting the government to avoid preparing for trial and permitting the court to allocate its resources efficiently, decrease the offense level by 1 level; and

(3) If the defendant otherwise clearly demonstrates acceptance of responsibility for the offense, decrease the offense level by 1 level.

(b) Notwithstanding the above, if the defendant's offense level determined prior to the operation of this guideline is below 16, decrease the offense level by no more than 2 levels for this guideline.

\section{NOTES}

${ }^{1}$ Appeals involving this guideline number third among appeals by defendants (only those involving the drug guidelines and relevant conduct were more numerous), and third among appeals by the government (only those involving the drug guidelines and departures were more numerous). Tables 66 and 67, 1994 ANNUAL REPORT, U.S. Sentencing Commission.

${ }^{2}$ See numerous factors and interface of factors discussed in case annotations in FEDERAL SENTENCING Guidelines HANDBOOK, Roger W. Haines, Jr., Editor, pp. 473482, 1994 edition.

${ }^{3} 1994$ AnNuAl RePort, U.S. Sentencing Commission, p. 146. Another quarter of the appeals involved "conduct necessary to receive the adjustment," and another quarter involved whether the defendant admitted conduct compris- ing the offense or how timely the notice of plea was. Id.

${ }^{4}$ Amendment 351, Appendix C, Guidelines Manual (expanding Application Note 2).

${ }^{5}$ Amendment 459, Appendix C, Guidelines Manual, effective November 1, 1992.

${ }^{6}$ However, one Justice has dissented from the Court's denial of certiorari to resolve the circuit split on the issue of whether denying the adjustment when the defendant refuses to disclose potentially incriminating information beyond the offense of conviction is a denial of the defendant's Fifth Amendment rights. Kinder v. U.S., 504 U.S. 946, 112 S. Ct. 2290 (1992) (mem.) (J. White, dissenting).

${ }^{7}$ The Court demonstrated that this principle has a limit, however, ten years earlier in U.S. v. Jackson, 390 U.S. 570, 572, 88 S. Ct. 1209 (1968), where it held that the state could not make the death penalty available only for defendants who go to trial.

${ }^{8}$ Similarly, the circuit courts have universally found that not only does $\S 3 \mathrm{E} 1.1$ not constitute a per se punishment for going to trial (see, e.g., U.S. v. Saunders, 973 F.2d 1354, 1362 (7th Cir. 1992) for thorough discussion), but, to the extent that it might chill the exercise of the right to go to trial, it is still constitutional, based on the reasons advanced by the Supreme Court in plea bargaining cases: even if a provision were to burden or chill a constitutional right, (1) the legitimate societal interest in conserving prosecutorial and judicial resources justifies the reward of a plea; and (2) the denial of the adjustment is the denial of a benefit, not the imposition of a penalty. See, e.g., U.S. v. Henry, 883 F. $2 \mathrm{~d}$ 1010 (11th Cir. 1989).

${ }^{9}$ Amendment 459, Appendix C, Guidelines Manual, effective November 1, 1992.

${ }^{10}$ Note 4 of the acceptance guideline, $\S 3 E 1.1$, says that only in an extraordinary case would acceptance of responsibility be awarded where obstruction has been imposed. 